\title{
PERAN KEPUASAN BELAJAR DALAM MENGUKUR MUTU PEMBELAJARAN DAN HASIL BELAJAR
}

\author{
Oleh \\ I Dewa Gede Rat Dwiyana Putra \\ Institut Hindu Dharma Negeri Denpasar \\ ratdwiyanaputra@gmail.com
}

diterima 20 September 2018, direvisi 25 Januari 2019, diterbitkan 28 Februari 2019

\begin{abstract}
Student's learning satisfaction is one of measuring tools of the success of learning process which would be realized through learning outcomes. This statement has been widely proven through various studies that have been done related to the learning satisfaction and learning outcomes. This article aims to describe three main points relating to the vital position of learning satisfaction as a determinant factor of student learning outcomes namely; (1) factors affecting learning satisfaction, (2) the influence of learning satisfaction on learning outcomes, and (3) how to measure learning satisfaction as well as examples of instruments that have been developed and used by researchers. The main source of this article was the research results from around the world that raised the learning satisfaction as the main topic. This paper was expected to provide an additional knowledge about learning satisfaction variables, so it can be utilized to carry out more in-depth research.
\end{abstract}

\section{Keywords: Learning Satisfaction, Learning Outcomes, Instrument}

\section{PENDAHULUAN}

Bangsa Indonesia adalah bangsa yang memberikan perhatian yang sangat besar pada sektor pendidikan. Pendidikan telah banyak disebut dalam berbagai wacana penting kenegaraan, mulai dari UUD 1945 hingga wacana Nawacita, pendidikan selalu menempati posisi penting dalam kelangsungan berbangsa dan bernegara. Hal ini membawa beberapa implikasi pada dunia pendidikan di Indonesia. Dari segi kurikulum pendidikan, mulai masa kemerdekaan hingga saat ini, pemerintah telah menyempurnakan kurikulum pendidikan di Indonesia sebanyak hampir delapan kali perubahan. Kurikulum pertama, "Rentjana Pembelajaran -Leer Plan" (Bahasa Belanda) di tahun 1947 disempurnakan menjadi "Rentjana Pembelajaran Terurai"pada tahun 1952, menjadi "Rentjana Pendidikan"pada tahun 1968, menjadi "Satuan Pelajaran"pada tahun 1975, kemudian disempurnakan 
kembali pada 1984 dan 1994 sebelum disempurnakan menjadi "Kurikulum berbasis Kompetensi" pada tahun 2004, dengan penyempurnaan menjadi "Kurikulum Tingkat Satuan Pendidikan" yang diaplikasikan secara resmi mulai tahun 2006, dan penyempurnaan terakhir pada tahun 2013 yang disebut dengan "Kurikulum 2013" (Cahyono \& Widiati, 2011:1-13; Lie, 2007:4; Kemendikbud, 2014; Putra, 2014:64). Penyempurnaan tersebt menunjukkan betapa besar perhatian pemerintah pada pendidikan yang dapat membawa kesejahteraan.

Disamping itu, dari segi penyelenggaran pendidikan, persaingan institusi pendidikan untuk memberikan pelayanan terbaik dan menunjukkan hasil terbaik tidak terelakkan. Persaingan tersebut terjadi pada setiap jenjang pendidikan, mulai dari jenjang pra-sekolah, sekolah dasar, sekolah menengah sampai dengan perguruan tinggi. Perguruan tinggi yang merupakan muara dari seluruh jenjang pendidikan yang ada dibawahnya mengalami kondisi persaingan yang lebih berat dari jenjangjenjang sebelumnya. Perguruan tinggi baik negeri maupun swasta terus bertumbuh dan berbenah untuk turut bersaing dalam memberikan pelayanan pendidikan. Sampai dengan saat ini terdapat 1.554 perguruan tinggi yang terakreditasi di BAN-PT (BANPT, 2016). Sementara itu lulusan sekolah menengah (SMA \& SMK) tiap tahunnya mencapai 2.548.389 (Kemdikbud, 2017). Dari data tersebut, rasio perguruan tinggi dan calon mahasiswa di Indonesia sekitar 1 : 1.500 (dikurangi kemungkinan tidak melanjutkan kuliah dan kuliah keluar negeri). Yang berarti jika seluruh calon mahasiswa disebarkan secara merata, setiap perguruan tinggi akan mendapatkan 1.500-an mahasiswa untuk dididik. Angka ini cukup besar bagi perguruan tinggi yang tiap tahunnya mungkin hanya menerima 100-500 siswa saja. Namun, persainganlah yang akhirnya menentukan apakah sebuah perguruan tinggi akan diminati atau tidak.

Banyak faktor yang mempengaruhi minat seorang siswa untuk memilih perguruan tinggi, diantaranya adalah; ketersediaan jurusan yang diminati, akreditasi jurusan yang diminati dan kualitas lulusan jurusan tersebut. Mulyatini, Suharyati dan Handayani, (2013) menyebutkan bahwa ada lima faktor utama yang menentukan seorang mahasiswa dalam memilih perguruan tinggi, yaitu; (1) Faktor fisik yang meliputi fasilitas, lingkungan dan gedung perpustakaan, (2) faktor jaminan kerja yang meliputi beasiswa, dosen, teman, keberhasilan alumni, memperoleh pekerjaan dan isu positif, (3) Faktor biaya kuliah yang meliputi biaya pendidikan, persyaratan pembayaran, keluarga dan penghasilan orang tua, (4) Faktor persepsi meliputi kurikulum dan citra PT, (5) Faktor promosi yang meliputi status akreditasi, dan potongan biaya pendidikan. Tujuan dari mahasiswa dengan menetapkan factor-faktor tersebut adalah agar kegiatan belajar dapat terlaksana dengan baik dengan biaya yang tidak terlalu mahal namun menjanjikan masa depan yang cerah. Jika hal tersebut dapat terwujud, mahasiswa akan merasa puas dalam menjalani pembelajaran sesuai dengan waktu yang ditentukan dan dapat mencapai suatu hasil belajar sesuai dengan yang diharapkan.

Oleh karena itu, faktor kepuasan belajar menempati posisi vital dalam mengukur kualitas suatu institusi pendidikan untuk nantinya dapat diminati oleh masyarakat. Tulian ini akan membahas lebih lanjut tentang faktor apa saja yang mempengaruhi kepuasan belajar siswa dan bagaimana kepuasan ini bissa mempengaruhi hasil belajar siswa. 


\section{PEMBAHASAN}

\subsection{Kepuasan Belajar}

Kepuasan merupakan suatu perasaan dimana harapan, kebutuhan dan keinginan dapat terpenuhi dari sebuah pelayanan (Aktan, 2010). Dalam kepuasan belajar, pelayanan yang dimaksud adalah pelayanan pembelajaran yang dirasakan oleh siswa. Oleh karena itu, kepuasan belajar dapat didefinisikan sebagai suatu kondisi perasaan puas karena terpenuhinya harapan dari sebuah kegiatan pembelajaran yang dialami oleh pelajar. $\mathrm{Wu}$, et.al (2015) juga menyebutkan bahwa teori tentang kepuasan belajar (learning satisfactory theory) merupakan sebuah teori yang dikembangkan dari teori kepuasan pelanggan/konsumen (customer satisfaction theory) oleh Cardozo (1965). Oleh karena itu, sejalan dengan teori kepuasan konsumen, teori kepuasan belajar memandang posisi siswa sebagai seorang konsumen yang mampu memberikan respon atas suatu kegiatan (belajar-mengajar) berdasarkan perbandingan antara harapan dan kenyataan yang mereka terima.

Kepuasan belajar juga dapat didefinisikan sebagai kemampuan emosional (emotional affordance) (Calli, et.al, 2013 dalam Ekoto 2015) atau persepsi subjektif (subjective perceptions) tentang suatu kondisi di mana pengalaman belajar siswa sesuai dengan harapan belajar siswa pada suatu mata pelajaran atau kursus (Lo, 2010 dalam Ekoto 2015). Hal ini sesuai dngan pernyataan Ko (2012) dalam Ko dan Chung (2014) yang menyebutkan bahwa kepuasan belajar adalah tingkat kepuasan siswa terhadap proses pembelajaran dan hasil yang didapatkan dari proses tersebut. Di tingkat perguruan tinggi, seorang siswa merupakan pelanggan dari suatu produk pendidikan dimana mereka memiliki hak untuk berinvestasi di suatu jurusan pada institusi pendidikan yang disukai. Jadi, kepuasan belajar siswa sangat penting untuk diperhatikan mulai dari faktor yang mempengaruhi kepuasan belajar sampai dengan faktor yang dapat dipengaruhi oleh kepuasan belajar.

\subsection{Faktor yang Mempengaruhi Kepuasan Belajar}

Markham dan Postema (2001) dalam Ekoto (2015) menyebutkan bahwa kepuasan belajar merupakan suatu faktor yang sangat kompleks, namun sangat diminanti untuk diteliti di dalam dunia pendidikan, terutama bagi peneliti yang mengadaptasi pendekatan teori konsumen. Penelitian-penelitian terdahulu telah membuktikan bahwa kepuasan belajar dipengaruhi oleh berbagai faktor, baik secara langsung maupun tidak langsung. Faktor-faktor tersebut dapat dikategorikan menjadi tiga kelompok utama yaitu;

\section{A. Faktor yang Berhubungan dengan Pengajar (Instructor-related Factors)}

\section{Kehadiran Pengajar}

Menurut sebuah penelitian yang dilaksanakan oleh Gray dan DiLoreto (2016) dalam sebuah kelas online, kehadiran pengajar masih berpengaruh secara signifikan terhadap kepuasan siswa. Kehadiran pengajar yang dimaksud disini bukan sekedar kehadiran pengajar secara fisik, namun juga mencakup kemampuan pengajar untuk mendesain, mengatur dan mengajar pada setiap kegiatan pembelajaran. Sehingga, walaupun pengajar tidak hadir di kelas, dengan memberikan konten pelajaran yang jelas, instruksi 
tertulis yang mudah dipahami maupun tugas-tugas yang relevan, pengajar sudah dapat dirasakan hadir di kelas (Gray dan DiLoreto, 2016).

Disamping itu, kehadiran pengajar juga dapat terwujud dalam bentuk diterimanya kualitas ersonal pengajar oleh siswanya. Hal ini akan memperngaruhi hubungan pengajar dan siswa dalam sebuah proses pembelajaran. Hubungan baik yang tercipta antara pengajar dan siswa, akan meningkatkan tingkat kepuasan siswa dalam belajar (Siming, et,al. 2015)

\section{Keahlian Pengajar}

Keahlian pengajar sangat erat kaitannya dengan tingkat pendidikan pengajar dan profesionalismenya sebagai seorang pengajar. Di tingkat perguruan tinggi, seorang pengajar harus memiliki tingkat pendidikan yang memadai dalam suatu bidang keahlian yang khusus sesuai dengan topic yang diajarkan. Bidang keahlian ini merupakan identitas seorang pengajar di perguruan tinggi yang melambangkan

profesionalismenya sebagai seorang pengajar. Butt dan Rehman (2010) menyatakan bahwa keahlian seorang pengajar merupakan faktor yang paling berpengaruh terhadap kepuasan belajar. Hal ini dapat terjadi karena seorang pengajar yang benar-benar professional, pasti mampu memberikan sebuah pengalaman pembelajaran yang professional sesuai dengan harapan siswa.
3. Struktur dan Organisasi Pembelajaran

Struktur dan organisasi pembelajaran mencakup seluruh pengaturan pembelajaran mulai dari kurikulum, silabus, pengembangan desain pembelajaran, sumber materi pembelajaran, metodologi, strategi, alokasi waktu, dan seluruh perencanaan mulai dari sebelum, selama dan sesudah pembelajaran (evaluasi/assessmen) (Garrison, Anderson, \& Archer, 2000 dalam Gray dan DiLoreto, 2016). Struktur dan organisasi pembelajaran ini pun terbukti berpengaruh secara positif dan signifikan terhadap kepuasan belajar, dimana semakin baik pengaturan struktur dan organisasi pembelajaran yang direncanakan dan diaplikasikan oleh pengajar, semakin meningkat pula kepuasan belajar yang dirasakan oleh siswa (Gray dan DiLoreto, 2016). Hal ini sesuai dengan hasil penelitian yang dikemukakan oleh Butt dan Rehman (2010) yang menyatakan bahwa program kelas atau rangkaian topik yang ditawarkan dalam sebuah kelas menjadi faktor penentu kepuasan siswa. Hal ini akan menentukan apakah materi yang akan diperoleh oleh siswa sesuai dengan harapan siswa tersebut. Jika program yang ditawarkan jauh dari bayangan yang diharapkan siswa, besar kemungkinan siswa tersebut akan merasakan ketidakpuasan yang akan menggangu kegiatan belajarnya. 


\section{Mutu Pembelajaran}

Mutu pembelajaran merupakan kualitas sebuah proses pembelajaran mulai dari tahap perencanaan sampai dengan evaluasi pembelajaran. Brown dan Kurzweil (2017) menyebutkan bahwa kualitas pembelajaran terdiri dari 2 aspek utama yaitu masukan pembelajaran (instructional input) dan keluaran pembelajaran (instructional output). Masukan pembelajaran dapat berupa peserta didik (dalam hal ini fokus kepada perilaku awal), materi pembelajaran, tenaga pengajar, dan proses pembelajaran itu sendiri. Sementara keluaran pembelajaran dapat berupa hasil pembelajaran, hasil penilaian kemampuan siswa, atau penentuan minat siswa (dapat bervariasi dalam berbagai seting pembelajaran). Posisi kepuasan belajar siswa berada pada kelompok keluaran pembelajaran, karena sesuai dengan definisi kepuasan belajar diatas, kepuasan siswa pada umumnya terjadi selama proses dan di akhir pembelajaran. Oleh karena itu, kepuasan belajar dapat digunakan sebagai tolak ukur kualitas/mutu pembelajaran.

Beberapa penelitian telah dilaksanakan untuk mengukur mutu pembelajaran melalui kepuasan belajar siswa. Ko dan Chiu (2011) dalam Ko dan Chung (2014) menyebutkan bahwa, kualitas pembelajaran merupakan suatu kebijakan institusional yang berisikan standar tentang proses pembelajaran yang memiliki karakter yang unik dan tepat untuk diterapkan dalam suatu pembelajaran, yang kemudian diaplikasikan oleh pengajar dalam bentuk langkah pembelajaran dan penentuan tujuan pembelajaran yang diharapkan mampu memenuhi harapan siswa serta orangtua siswa. Secara empiris, Ko dan Chung (2014) telah membuktikan bahwa kualitas pembelajaran yang dilaksanakan oleh seorang guru mampu meningkatkan kepuasan belajar siswa. Dalam penelitiannya, kualitas embelajaran yang dimaksud mempunyai 3 komponen utama yaitu; kemampuan pendidikan, penguasaan topic serta semangat dan sikap dalam pembelajaran. Pernyataan ini juga didukung oleh Siming, et.al. (2015) yang menebutkan bahwa ketika pengajar lebih serius menyiapkan dan menyampaikan materi pembelajarannya, siswa akan menunjukkan kepuasan yang tinggi juga. Disamping itu, jika siswa memiliki persepsi positif terhadap cara pengajar dalam memberikan tugas dan melakukan penilaian, siswa akan menunjukkan tingkat kepuasan yang tinggi (Suarman, Aziz, dan Yasin, 2013).

\section{B. Faktor yang Berhubungan dengan Pelajar (Learner-Related Factors)}

\section{Motivasi Siswa}

Motivasi yang dimaksud disini mengkhusus kepada motivasi siswa untuk maju dan berkembang (progress motivation). Motivasi untuk maju (progress motivation) 
merupakan kekuatan penggerak yang dimiliki oleh individu untuk maju dan berkembang. Dalam sebuah proses pembelajaran, jika siswa mempunya motivasi tinggi untuk maju dan berkembang, dia akan memperhatikan pembelajaran, berpartisipasi dalam pembelajaran, mengerjakan tugas dengan tuntas, dan dia akan menunjukkan kemajuan yang pesat di akhir pelajaran (Seyff 1379; Kdiv 2002 dalam Safari dan Korjanie, 2016).

\section{Partisipasi Siswa}

Partisipasi siswa dalam pembelajaran merupakan salah satu faktor penting yang nantinya akan menentukan tingkat kepuaan siswa terhadap suatu proses pembelajaran. Peran serta siswa (students engagement) dapat diartikan sebagai kemauan, kebutuhan, hasrat, dan ketertarikan untuk berpartisipasi dan sukses dalam sebuah proses pembelajaran (Bomia, Beluzo, Demeester, Elander, Johnson, \& Sheldon, 1997 dalam Gray dan DiLoreto, 2016). Disamping itu, partisipasi siswa juga merupakan bentuk ketertarikan siswa atas proses pembelajaran yang terwujud melalui interaksi siswa di kelas, motivasi untuk mempelajari topik pembelajarn dan lain sebagainya (Briggs, 2015 dalam Gray dan DiLoreto, 2016)

\section{Faktor yang Berhubungan dengan}

\section{Lingkungan Belajar (Learning}

\section{Environment-Related Factors)}

\section{Lingkungan Belajar}

Lingkungan belajar yang kondusif, asri dan menyenangkan sangat berkaitan dengan kepuasan belajar siswa. Butt dan Rehman (2010) menyebutkan bahwa, untuk kepuasan belajar siswa sangat ditentukan oleh lingkungan belajarnya. Siswa akan merasakan suatu kenyamanan dan kepuasan belajar ketika berada di lingkungan belajar yang baik. Siswa tentu saja tidak akan dapat belajar jika keadaan disekitarnya kotor, bising, tidak rapi, panas, pengap, dan lain sebagainya. Keadaan lingkungan tidak hanya mempengaruhi kenyamanan dan kepuasan siswa, melainkan juga keadaan psikologinya (Aina, 2015). Keadaan psikologi siswa yang buruk akan mengakibatkan turunnya partisipasi siswa, meningkatnya ketidak hadiran siswa, meningkatnya angka dropout, dan masalah-masalah lainnya (Ainley 1991; Reyes \& Jason 1993 dalam Aina, 2015) Melalui hasil penelitiannya, Butt dan Rehman (2010) juga merekomendasikan kepada pengelola pendidikan untuk memberikan perhatian khusus pada lingkungan belajar.

\section{Fasilitas Kelas}

Butt dan Rehman (2010) juga menegaskan bahwa fasilitas kelas dapat mempengaruhi kepuasan siswa. Fasilitas pendukung pembelajaran dan pelayanan isntitusi metupakan tolak ukur kepuasan belajar siswa (Siming, et.al. 2015). Fasilitas standar kelas seperti bangku belajar, papan tulis (hitam/putih) kapur/spidol, dan pengahapus merupakan fasilitas yang setidaknya harus ada di sebuah kelas. Disamping itu, 
fasilitas lain seperti Laptop, LCD proyektor, AC atau kipas angina, dan lain sebagainya, merupakan fasilitas tambahan yang dapat memberikan nilai tambah untuk mendukung kegiatan belajar. Aina (2015) menemukan bahwa siswa yang belajar di sekolah dengan fasilitas lengkap dan fungsional, menunjukkan tingkat kepuasan yang tinggi. Jadi, disamping fasilitas tersebut tersedia, pemeliharan dan perawatan fasilitas tersebut menjadi hal yang tidak kalah penting untuk menjaga agar fasilitas yang tersedia tetap dapat dipergunakan dengan baik.

\subsection{Pengaruh Kepuasan Belajar terhadap Hasil Belajar}

Hasil belajar (Learning Performance) merupakan sebuah kapasitas yang dapat ditunjukkan oleh siswa setelah melalui suatu proses belajar. Perubahan ini dapat berupa perubahan tingkah laku atau perubahan kemampuan. Definisi yang lain juga diungkapkan oleh Shuell, (1986) dalam Ko dan Chung (2014) yang menyatakan bahwa hasil belajar merupakan perubahan tingkah laku atau kemampuan siswa secara permanen karena pembelajaran, latihan dan pengalaman. Perubahan tingkah laku sangat penting untuk diperhatikan karena hal ini merupakan suatu bentuk tolak ukur akan kesuksesan proses pembelajaran yang telah terlaksana. Pengukuran keberhasilan belajar dapat dilakukan dengan berbagai cara, mulai dari cara klasik (test) ataupun observasi tingkah laku peserta didik yang lebih bersifat autentik. Tetapi, diluar berbagai pendekatan penilaian yang digunakan, pengukuran kepuasan siswa dapat digunakan sebagai suatu tolak ukur hasil belajar siswa.
Berbagai penelitian telah dilaksanakan untuk meninvestigasi hubungan antara kepuasan belajar dan hasil belajar. Ko dan Chung (2014) membuktikan bahwa, kepuasan siswa mampu meningkatkan pengaruh positif dari kualitas pembelajaran terhadap hasil belajar. Dengan kata lain, jika proses pembelajaran dapat dilaksanakan dengan kualitas yang baik, kepuasan siswa akan meningkat dan disertai hasil belajar yang meningkat pula. Hubungan positif terbut menandakan bahwa dalam melaksanakan pembelajaran, seorang guru juga harus memperhatikan kepuasan siswa disamping kualitas materi, metode dan system penilaian pembelajaran. Penelitian lain juga dilakukan oleh Dhaqane \& Afrah (2016) yang mencoba untuk menemukan hubungan antara kepuasan belajar siswa dan hasil belajar siswa. Dalam penelitiannya, 133 mhasiswa tahun ke-3 dan ke-4 di Universitas Benadir, Somalia, berpartisipasi dalam menjawab survei tentang kepuasan belajar dan hasil belajar. Hasil penelitiannya menunjukkan bahwa kepuasan belajar berpengaruh positif terhadap hasil belajar serta daya ingat siswa. Hal tersebut menunjukkan betapa pentingnya kepuasan belajar dalam menentukan hasil belajar. Hal ini juga sesuai dengan pernyataan Hassani dan Aghdasi (2014) dalam Dhaqane \& Afrah (2016) yang menyebutkan bahwa hal utama yang menentukan kesuksesan siswa dalam pembelajaran bukan hanya tercermin dari nilai akademis semata, melainkan juga dari perasaan puas akan pengalaman yang didapatkan dari pembelajaran tersebut.

\subsection{Instrumen Pengukuran Kepuasan Belajar \\ Topala dan Tomozii (2013)} mengembangkan sebuah kuesioner yang dapat digunakan untuk mengukur kepuasan belajar siswa berdasarkan enam faktor 
utama, yaitu; (1) karakteristik individu (individual characteristics), (2) kondisi sarana dan pra-sarana belajar (material conditions and learning facilities), (3) pengajar dan kegiatan pembelajaran (the teacher and the instructional activity), (4) hasil belajar (learning outcomes), (5) lingkungan pembelajaran (learning environment), dan (6) hubungan antar peserta didik (peer relationships). Students' Learning Satisfaction Questionnaire (SLSQ) atau quesioner kepuasan belajar siswa ini terdiri dari terdiri dari 26 item yang masingmasing diukur menggunakan skala Likert 6 level, yaitu 1 = sangat tidak puas s/d $6=$ sangat puas. Quesioner tersebut telah diuji coba kepada 80 subjek dengan hasil yg menunjukkan bahwa instrument tersebut dapat mengukur kepuasan belajar siswa dengan valid dan reliabel dengan tidak membedakan unsur dari faktor karakter individu dan hasil belajar. Hal ini menjadi celah untuk menyempurnakan instrumen ini.

Pengukuran kepuasan juga dapat dilakukan dengan menggunakan empat aspek kepuasan siswa yang digunakan oleh Ko dan Chung (2014), yaitu; (1) kepuasan terhadap perencanaan pembelajaran (satisfaction with instructional planning), (2) kepuasan terhadap pengaturan prosedur (satisfaction with arrangement of procedure),

kepuasan terhadap pengaturan waktu (satisfaction with time arrangement), dan (4) kepuasan terhadap desain kurikulum (satisfaction with curriculum design). Berbagai item pertanyaan dapat dikembangkan dari faktor tersebut, sesuai kebutuhan untuk mengukur kepuasan belajar siswa. Namun, masih banyak kesempatan bagi para peneliti yang tertarik untuk mengembangkan instrument kepuasan belajar siswa.

\section{KESIMPULAN}

Kepuasan belajar mungkin merupakan salah satu faktor yang sangat kompleks untuk didefinisikan secara deskriptif. Namun, pembahasan diatas telah mengantarkan kita pada suatu kesimpulan bahwa ada beberapa atribut penting yang perlu diperhatikan untuk menggambarkan kepuasan belajar. Yang pertama adalah adanya faktor-faktor penentu kepuasan belajar siswa yang masing-masing terkait dengan pengajar, pelajar dan lingkungan belajar. Faktor yang berkaitan dengan pengajar meliputi, kehadiran pengajar, keahlian pengajar, organisasi pembelajaran dan mutu pembelajaran. Faktor yang berkaitan dengan pelajar meliputi, motivasi dan partisipasi siswa. Faktor yang berhubungan dengan lingkungan belajar meliputi lingkungan belajar dan fasilitas kelas. Dari penjelasan diatas, jelas sekali terlihat bahwa faktor-faktor yang mempengaruhi kepuasan belajar sendiri bukanlah faktor yang berdiri sendiri, melainkan terintegrasi dan mempengaruhi kepuasan belajar siswa secara komprehensif. Dengan kata lain, faktor yang berhubungan dengan pengajar juga memiliki beberapa unsur yang berkaitan dengan faktor yang berhubungan dengan lingkungan belajar. Jadi, faktor faktor tersebut tidak bekerja sendiri, dan seluruh pihak yang berkaitan langsung dalam suatu lingkungan pembelajaran harus bersinergi untuk menciptakan suatu pengalaman belajar yang dapat memuaskan siswa.

Setelah kepuasan siswa terwujud, salah satu faktor penting yang kemudian dipengaruhi oleh kepuasan siswa ini adalah hasil belajar siswa. Hasil belajar siswa tidak dapat diartikan sebagai nilai semata, namun lebih kompleks daripada itu. Hasil belajar mencakup keberhasilan siswa dalam meningkatkan kemampuanya baik secara 
kognitif, afektif dan psikomotorik. Oleh karena itu pengalaman belajar yang memuaskan siswa dapat memberikan suatu perubahan yang berarti pada siswa yang diterima sebagai peningkatan diri yang bermakna (meaningful self-improvement). Bukti-bukti tentang adanya hubungan positif antara kepuasan belajar dan hasil belajar telah dibuktikan melalui penelitian oleh para ahli (Ko dan Chung, 2014; Dhaqane \& Afrah, 2016). Oleh karena itu, pelaku pendidikan sebaiknya mulai memperhatikan kepuasan belajar siswa untuk menjadi acuan dalam mengevaluasi kegiatan instruksional yang telah berlangsung. Atau, tingkat kepuasan belajar siswa juga dapat digunakan sebagai pembanding hasil supervisi kegiatan pembelajaran yang dilakukan oleh pengawas atau penjamin mutu institusi pendidikan.

\section{Daftar Pustaka}

Aina, S.I. 2015. Effects of School Facilities on pupil's Satisfaction with Schooling in Ondo State, Nigeria. Journal of Emerging Trends in Educational Research and Policy Studies (JETERAPS) 6(2): 146-149. http://jeteraps.scholarlinkresearch.co $\mathrm{m} /$ articles/Effects $\% 20$ of $\%$ 20School\%20Facilities.pdf

Aktan, F. 2010. The Effects of Learner Characteristics on Satisfaction in Distance Education. Published thesis. The Ohio State University. https://etd.ohiolink.edu/!etd.send _file?accession $=$ osu $1281368302 \&$ dis position=inline

BAN-PT.2016. Direktori Hasil Akreditasi Program Studi. (Online) (https://banpt.or.id/ direktori/prodi/pencarian_prodi) accessed on $19^{\text {th }}$ October 2017

Butt, B.Z., Rehman, K.U. 2010. A study examining the students satisfaction in higher education. Article of WCES 2010. Procedia Social and Behavioral Sciences, 2(2010) 5446-
5450.

DOI:10.1016/j.sbspro.2010.03.888

Brown, J., \& Kurzweil, M. 2017. Instructional Quality, Student Outcomes, and Institutional Finances. Washington, DC: American Council on Education. http://www.acenet.edu/ newsroom/Documents/InstructionalQuality-Student-Outcomes-andInstitutional-Finances.pdf

Cahyono, B.Y. \& Widiati, U. 2011. The Teaching of English as a Foreign Language in Indonesia. Malang: State University of Malang Press

Cardozo, R. (1965). An experimental study of customer effort, expectation and satisfaction. Journal of Marketing Research, 2(3), 244-249. DOI: $10.2307 / 3150182$

Dhaqane, M.K., \& Afrah, N.A. 2016. Satisfaction of Students and Academic Performance in Benadir University. Journal of Education and Practice, 7(24), 59-63. https://files.eric.ed.gov/fulltext/EJ111 2855.pdf

Ekoto, C.E., Gaikwad, P. 2015. The Impact of Andragogy on Learning Satisfaction of Graduate Students. American Journal of Educational Research, 3(11), 1378-1386. DOI: 10.12691/education-3-11-6

Gray, J.A., DiLoreto, M. 2016. The Effects of Student Engagement, Student Satisfaction, and Perceived Learning in Online Learning Environments. NCPEA International Journal of Educational Leadership Preparation, 11(1), 1-20. https://files.eric.ed.gov/fulltext/ EJ1103654.pdf

Kementerian Pendidikan dan Kebudayaan. 2014. Paparan Wakil Menteri Pendidikan dan Kebudayaan R.I Bidang Pendidikan: Konsep dan Implementasi Kurikulum 2013. (Online), (https://kemdikbud.go.id/kemdikbud/ dokumen/Paparan/Paparan\%20 
Wamendik.pdf) accessed on $5^{\text {th }}$ October 2017

Kemdikbud. 2017. Ikhtisar Data Pendidikan

Tahun 2016/2017. Jakarta:PDDS

Pendidikan dan Kebudayaan.

http://publikasi.data.kemdikbud.go.id

/uploadDir/isi_FC1DCA36-A9D8-

4688-8E5F-0FB5ED1DE869_.pdf

Ko, W.H., Chung, F.M. 2014. Teaching Quality, Learning Satisfaction, and Academic Performance among Hospitality Students in Taiwan. World Journal of Education, 4(5), 11-20. DOI:10.5430/wje.v4n5p11

Lie, A. 2007. Education Policy and EFL Curriculum in Indonesia: Between the Commitment to Competence and the Quest for Higher Test Scores. TEFLIN Journal, 18 (1), pp. 1-14. From http://teflin.org/journal/index.php/jou rnal/article/viewFile/48/53.

Mulyatini, S., Suharyati, \& handatani, T. 2013. Faktor-Faktor yang Berpengaruh terhadap Keputusan Memilih Program Studi. Journal \& Proceeding FEB UNSOED, SCA3,(1), 1-15. http://jp.feb.unsoed.ac.id/index.php/s ca-1/article/viewFile/243/248

Putra, K.A. 2014. The Implication of Curriculum Renewal on ELT in Indonesia. PAROLE: Journal of Linguistics and Education, 4 (1), pp. 63-75. From http://ejournal.undip. ac.id/index.php/parole/article/view/63 15

Safari, S., Korjanie, E. 2016. The progress motivation effect on the students learning satisfaction (Case study on smart high schools). International Journal of Humanities and Cultural Studies, 2016 Special
Issue, 418-433. https://www.ijhcs.com/index.php/ijhc s/article/view/ 823/764

Siming, L., Niamatullah, Gao, J., Xu, D., Shafi, K. 2015. Factors Leading to Students' Satisfaction in the Higher Learning Institutions. Journal of Education and Practice, 6(31), 114118.

https://files.eric.ed.gov/fulltext/EJ108 3362.pdf

Suarman, Aziz, Z. dan Yasin, R.M. 2013. The Quality of Teaching and Learning towards the Satisfaction among the University Students. Asian Social Science, 9(12), 252-260. doi:10.5539/ass.v9n12p252

Triyana, I. G. N. (2017). Penjaminan Mutu Pendidikan Melalui Teknologi Informasi Di Institut Hindu Dharma Negeri Denpasar. Jurnal Penjaminan Mutu, 3(1), 119-126.

Topala, I., \& Tomozii, S. 2013. Learning satisfaction: validity and reliability testing for students' learning satisfaction questionnaire (SLSQ). EPC-TKS 2013. Procedia - Social and Behavioral Sciences, 128 (2014), 380 - 386. https://goo.gl/ungvLb

Wu, Y.C., Hsieh, L.F., Lu, J.J. 2015. What's The Relationship Between Learning Satisfaction and Continuing Learning Intention?. Article of WCES 2014. Procedia - Social and Behavioral Sciences 191(2015), 2849 - 2854. DOI: 10.1016/j.sbspro.2015.04.148

Zhu, C. 2012. Student Satisfaction, Performance, and Knowledge Construction in Online Collaborative Learning. Educational Technology \& Society, 15 (1), 127-136. new.ifets.info/index.php/ifets/article/ download/18/12 